\title{
NEW LOCALITY OF RARE SAPROXYLIC BEETLE ENEDREYTES SEPICOLA (FABRICIUS, 1792) (COLEOPTERA: ANTHRIBIDAE) IN POLAND WITH REMARKS ON THE BIOLOGY AND DISTRIBUTION OF THE SPECIES
}

\author{
Damian Bruder ${ }^{1}$, Adrian Łukowski ${ }^{2,3 凶}$ \\ ${ }^{1}$ Department of Forest Entomology, Poznań University of Life Sciences \\ Wojska Polskiego 71D, 60-625 Poznań, Poland \\ ${ }^{2}$ Institute of Dendrology, Polish Academy of Sciences \\ Parkowa 5, 62-035 Kórnik, Poland \\ ${ }^{3}$ Department of Game Management and Forest Protection, Poznań University of Life Sciences \\ Wojska Polskiego 71D, 60-625 Poznań, Poland
}

\begin{abstract}
In Poland, Enedreytes sepicola (Coleoptera: Anthribidae) has been reported from places dispersed almost all over the country and occurred it in small numbers everywhere. In this study we described a new locality found in the Nowa Sól Forest District, Regional Directorate of the State Forests in Zielona Góra (UTM: WT53) and we contributed to the knowledge of the distribution of this rare and locally occurring species of the family Anthribidae. Eight beetles were reared from dead branches of hornbeam (Carpinus betulus). The locality in the Nowa Sól Forest District is one of the outermost west-situated place of occurrence of this species in Poland, and also the first one reported in the forests of the Lubusz Voivodeship. Furthermore, a brief summary has been made of data concerning the biology, ecology and distribution of this saproxylic species, on the basis of national and foreign literature.
\end{abstract}

Key words: Anthribidae, Coleoptera, Enedreytes sepicola, geographical distribution, new record

\section{INTRODUCTION}

Beetles (Coleoptera) are one of the largest orders of insects. They cover about 400 thousand species known to science of which approx. $16 \%$ are those belonging to the superfamily of Curculionoidea (Hammond, 1992). Among the beetles occurring in forests, one can distinguish commonly encountered and very rare species from a wide ecological spectrum required for the development of the large-scale forest complexes. The size of a forest determines the occurrence of specific microhabitats in which the mentioned group finds suitable conditions for its development. These rarely occurring species are often referred to as the relics of natural or primary forests (Borowski, 2007). The presence of the relict species may indicate a relatively low transformation made by a man of the given ecosystem (Borowski, 2007; Tylkowski, 2014). Moreover, beetles are the largest group among the saproxylic insects, which are the organisms obligatory or facultatively connected with the wood of the dead or dying trees (Plewa et al., 2014). 
About 1,300 saproxylic beetles have been noted in Poland, what constitutes about $21 \%$ of all local Coleoptera (Gutowski, 2006) and their biggest number is connected with the oak wood (Ammer, 1991). As it is reported by Plewa et al. (2014), there is an urgent need for research and observation of saproxylic beetles in connection with their biology and ecology, environmental preferences and in particular with their locality. The primary goal of any inventory of species in a particular area is to create an accurate map of the occurrence based on the obtained data which then provide a basis for developing the extent of occurrence on the national scale (Chrzanowski et al., 2013). The state of knowledge on the insects' locality in the successive Polish regions is still uneven, including those orders which are considered to be well recognized (eg. butterfly; Buszko, 1997). It is therefore important to conduct a comprehensive inventory on a local scale (tukowski, 2015), especially of the less common taxonomic groups of insects (Borowski and Kieszek, 1999).

The aim of this paper is to contribute to the knowledge of locality in Poland of rarely or locally occurring member of the Anthribidae family: Enedreytes sepicola. The paper also presents a synthetic overview of the data concerning biology, ecology and the locality of the above mentioned species with notes concerning the Anthribidae family on the basis of the national and foreign literature.

\section{MATERIAL AND METHODS}

Nowa Sól Forest District (Regional Directorate of State Forests in Zielona Góra; Wielkopolsko-Kujawska Lowland) is located on the area of 13 squares in accordance with the UTM system $10 \times 10 \mathrm{~km}:$ WT23, WT24, WT32, WT33, WT34, WT42, WT43, WT44, WT52, WT53, WT54, WT63, WT64. Field studies were ultimately carried out only within a UTM square: WT53. The data were collected in 2014 and 2015 during which a variety of habitats within the forest district were penetrated in the search of places with a lot of dead wood. In December 2014, the initial inventories were carried out in order to select the research positions. The surface in the Odra Forestry (division and separation: 232n) was selected. The share of oaks in this separation is $90 \%$ (146 years old), and hornbeam covers the remaining area (103 years old). In addition, it is the Natura 2000 - Habitats Directive "Nowosolska Odra Valley" code no: PLH080014 and the bird area Natura 2000 "Central Odra River Valley" code no: PLB080004. The nearest village is Siedlisko.

Dead branches of oak and hornbeam were randomly collected on the above mentioned surface on January 31, 2015. They were placed in breeding tubes maintaining adequate moisture necessary for the development of the wood decaying fungi. The collected plant material was stored at room temperature. The chosen material at its thickest point ranged from 2 to $2.5 \mathrm{~cm}$ in diameter. The branches were kept in the tubes until May 2015. The bred insects were identified to the rank of species. The specimens were prepared and then their gender was determined. The collected, as the result of the research, evidence material does not contain species protected by law and is currently deposited in the collection of the main author. Naming and systematic arrangement were adopted in accordance to Wanat and Mokrzycki (2005).

\section{RESULTS AND DISCUSSION}

Enedreytes sepicola Fabricius, 1792 (Fig. 1) has been found in the discussed area among many widespread species of beetles. From the obtained plant material

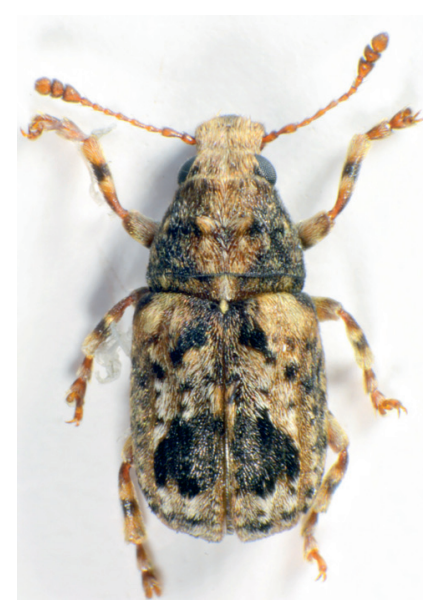

Fig. 1. Male of Enedreytes sepicola (Fabricius, 1792) from D. Bruder's collection (photo by R. Witkowski)

Rys. 1. Samiec Enedreytes sepicola (Fabricius, 1792) z kolekcji D. Brudera (fot. R. Witkowski) 
Bruder, D., Łukowski, A. (2016). New locality of rare saproxylic beetle Enedreytes sepicola (Fabricius, 1792) (Coleoptera: Anthribidae) in Poland with remarks on the biology and distribution of the species. Acta Sci. Pol. Silv. Colendar. Ratio Ind. Lignar., 15(3), 137-144. DOI: 10.17306/J.AFW.2016.3.16

8 E. sepicola $(5 \hat{\bigcirc}$ and 3 P $)$ specimen were reared. Imagines appeared from $17^{\text {th }}$ to $23^{\text {rd }}$ March $2015\left(17^{\text {th }}\right.$ March 2 exx.; $19^{\text {th }}$ March 2 exx.; $21^{\text {st }}$ March 1 ex.; $22^{\text {nd }}$ March 2 exx.; $23^{\text {rd }}$ March 1 ex.). All grown specimens come from 3 branches of hornbeam Carpinus betulus L. (Fig. 2). The locality of this species in the Nowa Sól Forest District is one of the outermost to the west-situated places of existence in Poland and it is also its first finding in the woods of the Lubuskie Voivodeship. This observation confirmed its presence on the area of the Wielkopolska-Kujawy Lowland.

The Anthribidae Billberg family belongs to the Polyphaga suborder within it to the Curculionoidea superfamily. The phylogeny of the Curculionoidea superfamily shows that the Anthribidae are the primal group of weevils (Marvaldi et al., 2002; Marvaldi et al., 2009). This family is characterized by a great morphological and ecological diversity. Its global diversity is associated with mycetophagy of its larvae and adults develop mainly on wood-decaying fungi of the Ascomycota type (Holloway, 1982; Oberprieler et al., 2007), which is rare among beetles as they generally prefer different groups of the Basidiomycetes (Basidiomycota) type. The locality of Anthribidae covers the whole Southern Europe, Central and Eastern Asia, Southern Africa, Central and Northern America, Australia and New Zealand. There are 3860 species known (in 1989: 3000 species were approximately known; Cmoluch, 1989) which homeland are mainly tropical countries (Rheinheimer, 2004). In Central Europe, the family is represented by about 30 species out of which 23 are found in Poland (Cmoluch, 1989; Wanat and Mokrzycki, 2005). However, Burakowski et al. (1992) indicates that Ulorhinus bilineatus Germar was vaguely disclosed from Silesia over a hundred years ago probably on the basis of an erroneous marking of the specimen. Therefore, it can be assumed that 22 species of the Anthribidae family have been recorded reliably on the Polish territory (Stachowiak, 2002).

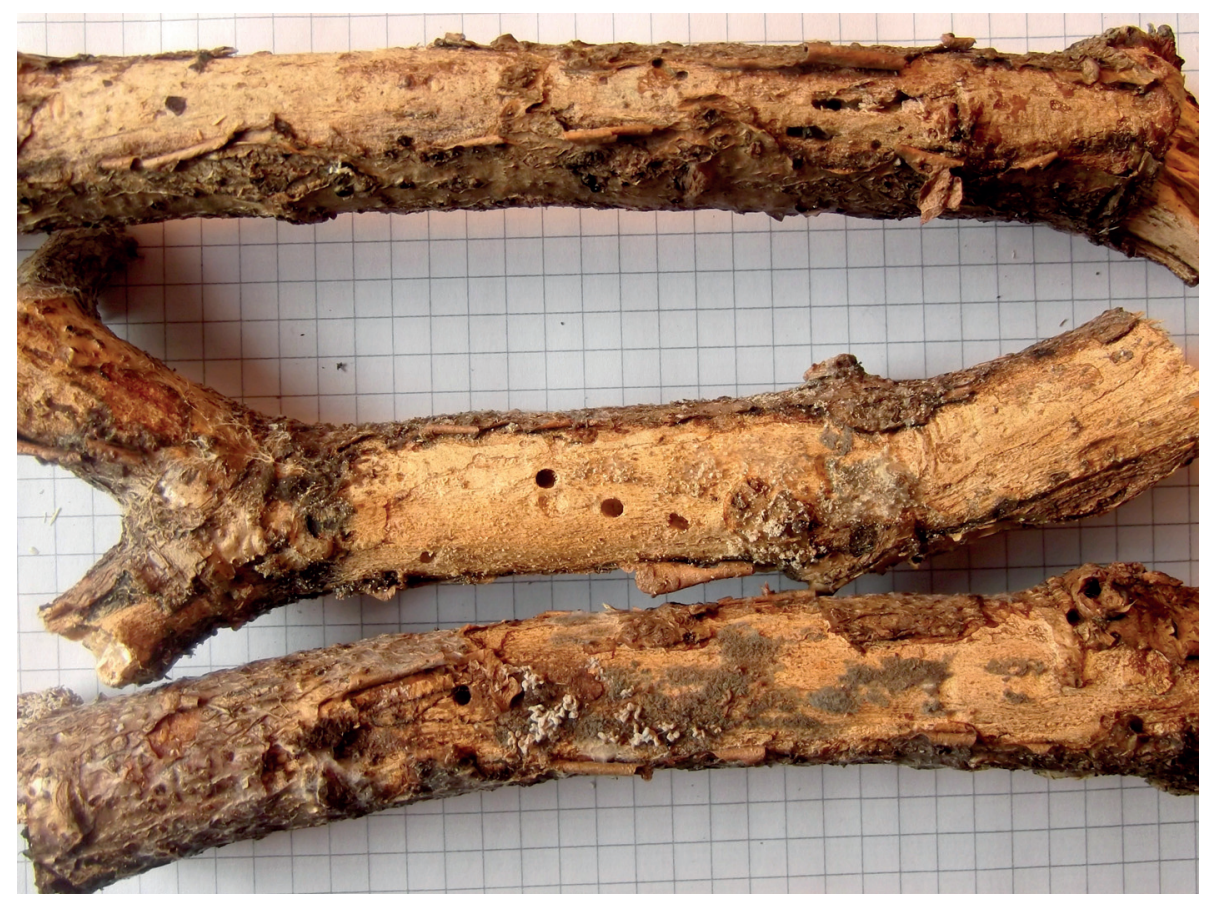

Fig. 2. Feeding ground of Enedreytes sepicola (Fabricius, 1792) on common hornbeam (Carpinus betulus L.) with imago exit holes (photo by D. Bruder)

Rys. 2. Żerowisko Enedreytes sepicola (Fabricius, 1792) na grabie pospolitym (Carpinus betulus L.) z widocznymi otworami wylotowymi imagines (fot. D. Bruder) 
Bruder, D., Łukowski, A. (2016). New locality of rare saproxylic beetle Enedreytes sepicola (Fabricius, 1792) (Coleoptera: Anthribidae) in Poland with remarks on the biology and distribution of the species. Acta Sci. Pol. Silv. Colendar. Ratio Ind. Lignar., 15(3), 137-144. DOI: 10.17306/J.AFW.2016.3.16

The basic distinguishing features of Enedreytes Schoenh genus are: pronotum with two tufts of raised hair and slightly wavy but pronounced rib in its back part and eyes set very wide apart. Beetles of this kind are polyphags and they feed on trees and shrubs of the following families: Betulaceae, Fagaceae, Salicaceae and Hippocastanaceae. In Central Europe, the genus Enedreytes is represented by one species, E. sepicola Fabricius (= Pseudeuparius sepicola; Cmoluch, 1989). Enedreytes sepicola (Fig. 1), as the mycetophagic species growing at the cost of mycelium overgrowing wood, has a generally long period of imagines appearance which is observed from April to September. It can be assumed that this species, like the majority of national representatives of this family, reveals exorbitant thermal preferences and the peak of their appearance falls in the summer months (Wanat et al., 2011). Larvae of E. sepicola are obligatorily associated with the occurrence of dead wood and develop in the rotting branches of various deciduous trees. As the main host plant species of larvae have been given oak Quercus L. (Wanat et al., 2011; Widerberg et al., 2012; Plewa et al., 2014), and occasional species such as beech Fagus L., chestnut $C a$ stanea Mill. or hornbeam Carpinus L. (Delbol, 2013).

The species was disclosed in majority of European countries, ie. Austria (Holzinger 2014), Belgium (Delbol, 2013), Bulgaria (Löbl and Smetana, 2011), Croatia (Löbl and Smetana, 2011), the Czech Republic (Nakládal, 2011), Denmark (Löbl and Smetana, 2011), France (Löbl and Smetana, 2011), Great Britain (Löbl and Smetana, 2011), Germany (Büche and Möller, 2005), Georgia (Löbl and Smetana, 2011), Hungary (György, 2006), Italy (Löbl and Smetana, 2011), Luxembourg (Braunert, 2009), the Netherlands (Heijerman, 1993), Poland (Wanat and Mokrzycki, 2005), Portugal (Löbl and Smetana, 2011), Serbia (Löbl and Smetana, 2011), Slovakia (Cunev and Majzlan, 1998), Spain (AlonsoZarazaga et al., 2004), Russia: South European Territory (Löbl and Smetana, 2011), Sweden (Widerberg et al., 2012), Switzerland (Löbl and Smetana, 2011), Turkey (Löbl and Smetana, 2011) and Ukraine (Löbl and Smetana, 2011). In some countries, it was included in the red list in the view of its rare occurrence where e.g. in the Czech Republic and Germany it received the EN category (endangered; Büche and Möller, 2005; Nakládal, 2011), and in Sweden the NT category (near threatened; Widerberg et al., 2012). In Poland this species is rarely met usually in limited quantity what is indirectly confirmed by a relatively small number of published faunal reports on them and a small number of specimens in entomological collections. However, Wanat et al. (2011) claim that such a belief about some beetles from the Anthribidae family may prove to be incorrect due to their secretive lifestyle and the specific biology which results in a very local presence in the area. The fact that they have never been the subject of intense faunal study and that they are generally ignored in the cooperative publications about different groups of weevils should be taken into account.

The current locality of E. sepicola in Poland was set out (Fig. 3) on the basis of the review of the literature data, as well as of the online database (Biodiversity Map - National Biodiversity Information Network). In Poland, this species was usually observed in small numbers in the central and southwestern parts of the country. The biggest number of data regards the locality of this species in the Wielkopolska-Kujawy Lowlands. It was last recorded by the research teams: Wanat et al. (2011) and Plewa et al. (2014) always in small numbers. Previously, it was reported in this area by other authors, such as: Schumann (1908), Szulczewski (1922), Bałazy and Michalski (1982; 1984), Cmoluch (1989) and Bałazy et al. (1989). It was also quite often registered in the Mazowsze Lowland: in the Rogów Forest District (Borowski and Kieszek, 1999) and in the Puławy Forest District (Plewa et al., 2014) and in the Kampinos National Park (Marczak and Masiarz, 2013). In addition, there are stable populations on the periphery of the main coverage of E. sepicola around Przemyśl (Trella, 1930; Cmoluch, 1989; Burakowski et al., 1992) and on the Baltic seacoast, in the areas of Puck (Węgrzecki, 1932; Cmoluch, 1989) and Elbląg (Cmoluch, 1989). Only historical data exist for the positions in the area of Silesia (Weigel, 1806; Kuhnt, 1912; Cmoluch, 1989), Lower Silesia (Schummel, 1847; Leder, 1872 Polentz, 1949), and the Carpathians (Nowicki, 1873).

The paper presents the summary of current knowledge about rare recorded beetle species Enedreytes sepicola. So far, the available information about the range of occurrence and biology of this species is still insufficient to accurately determine the number and locality in our country. In most cases, the existence is usually confirmed on the basis of the observations of a few individuals. This work completed the state 
Bruder, D., Łukowski, A. (2016). New locality of rare saproxylic beetle Enedreytes sepicola (Fabricius, 1792) (Coleoptera: Anthribidae) in Poland with remarks on the biology and distribution of the species. Acta Sci. Pol. Silv. Colendar. Ratio Ind. Lignar., 15(3), 137-144. DOI: 10.17306/J.AFW.2016.3.16

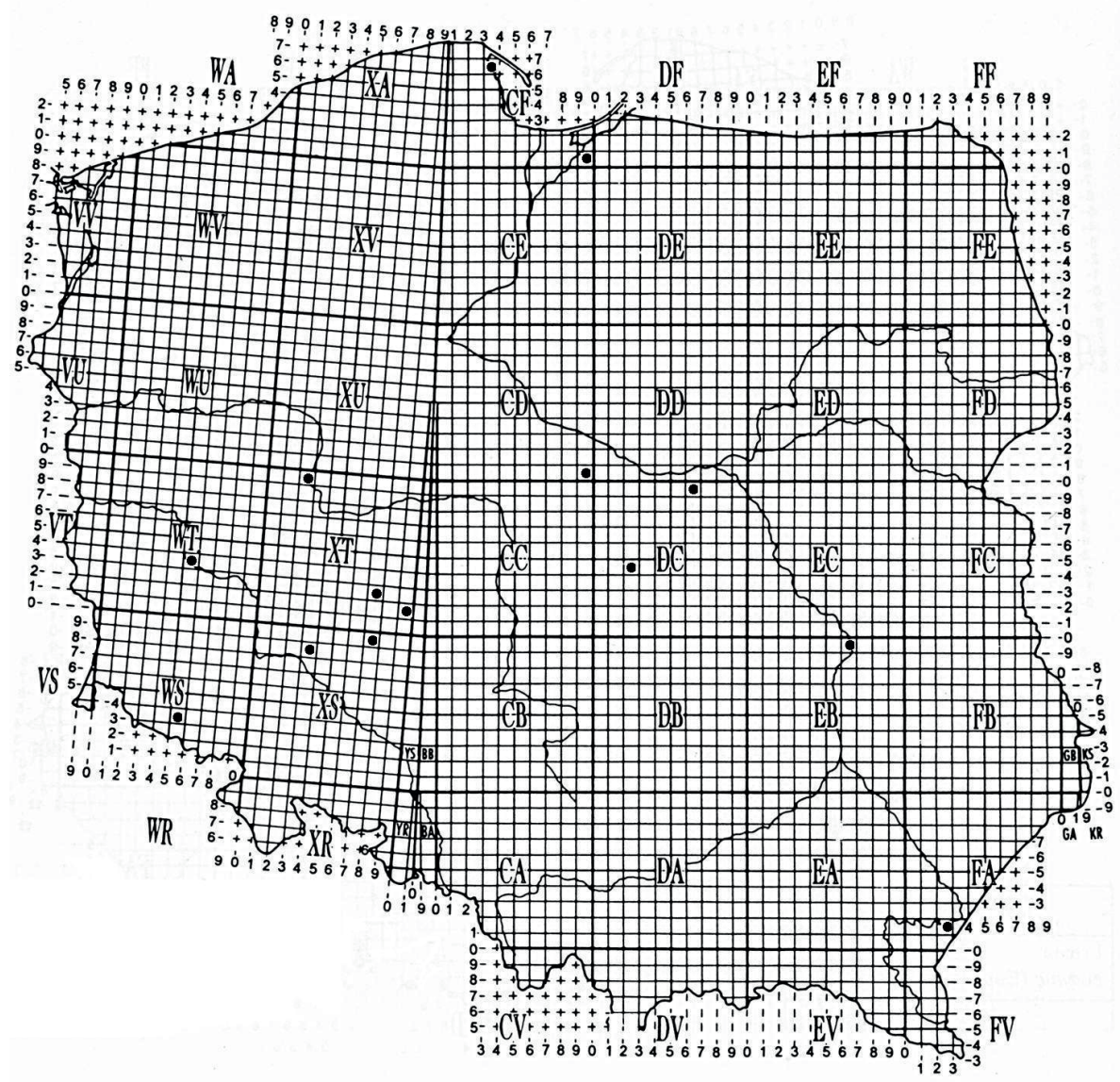

Chrząszcze I Motyle Polski - wnww.en tomo.bal.pl

Fig. 3. Distribution of Enedreytes sepicola in Poland with the new locality (UTM: WT53) (www.entomo.bai.pl)

Rys. 3. Rozmieszczenie Enedreytes sepicola w Polsce wraz z nowym stanowiskiem (UTM: WT53) (www.entomo.bai.pl)

of knowledge about the locality of this species in Poland with a new position in the Nowa Sól Forest District. However, the current data give us no more than a rough idea of the possible locality of this species, as well as they do not inform about the yearly number of the individual populations.

\section{REFERENCES}

Alonso-Zarazaga, M. Á., Moreno, I. P., Grijalba, F. M. (2004). New data for the Iberian distribution of Enedreytes sepicola (Fabricius, 1792) (Coleoptera, Anthribidae). Boletín de la SEA, 34, 209.
Ammer, U. (1991). Konsequenzen aus den Ergebnissen der Totholzforschung für die forstliche Praxis. Forstwiss. Centralblatt, 110(1), 149-157.

Bałazy, S., Michalski, J. (1982). Badania nad fauną ksylofagów Wielkopolskiego Parku Narodowego, IV [Studies on the xylophagous insects in Wielkopolski National Park, IV]. Bad. Fizjogr. Pol. Zach., C, 33, 139-145 [in Polish].

Bałazy, S., Michalski, J. (1984). Wstępna charakterystyka entomofauny drewna i środowiska podkorowego drzew w Wielkopolskim Parku Narodowym [Preliminary characterization of entomofauna of wood and the subcortical environment in Wielkopolski National Park]. Fol. For. Pol., A, 25, 163-184 [in Polish]. 
Bruder, D., tukowski, A. (2016). New locality of rare saproxylic beetle Enedreytes sepicola (Fabricius, 1792) (Coleoptera: Anthribidae) in Poland with remarks on the biology and distribution of the species. Acta Sci. Pol. Silv. Colendar. Ratio Ind. Lignar., 15(3), 137-144. DOI: 10.17306/J.AFW.2016.3.16

Bałazy, S., Banaszak, J., Michalski, J. (1989). Badania nad fauną ksylofagów Wielkopolskiego Parku Narodowego. V [Research on xylophagous insects in Wielkopolski National Park. V]. Aculeata - Żądłówki. Bad. Fizjogr. Pol. Zach., C, 38, 115-121 [in Polish].

Borowski, J., Kieszek, C. (1999). Ciekawsze chrząszcze (Coleoptera) odłowione w rezerwacie dębowym „Zimna Woda" w Rogowie [Interesting beetles (Coleoptera) caught in the oak reserve "Zimna Woda" in Rogów]. Wiad. Entom., 18(2), 125-126 [in Polish].

Borowski, J. (2007). Chrząszcze Insecta, Coleoptera - jako wskaźnik naturalności drzewostanów [Beetels Insecta, Coleoptera - as an indicator of naturalness of treestands]. Stud. Mat. Centr. Eduk. Przyr.-Leśn., 9(2/3[16]), 510-518 [in Polish].

Braunert, C. (2009). Verzeichnis der Rüsselkäfer Luxemburgs (Coleoptera, Curculionoidea) mit Ausnahme der Borkenkäfer (Scolytinae) und Kernkäfer (Platypodinae). Bull. Soc. Natur. Luxemb., 110, 125-142.

Buszko, J. (1997): Atlas rozmieszczenia motyli dziennych w Polsce (Lepidoptera: Papilio-noidea, Hesperioidea) 1986-1995 [Atlas of distribution of butterflies in Poland (Lepidoptera: Papilionoidea, Hesperioidea) 19861995]. Toruń: Ofic. Wyd. Turpress [in Polish].

Burakowski, B., Mroczkowski, M., Stefańska, J. (1992). Chrząszcze - Coleoptera. Ryjkowcowate prócz ryjkowców - Curculionioidea prócz Curculionidae [Beetles Coleoptera. Curculionioidea apart Curculionidae]. Katalog Fauny Polski 18. Warszawa [in Polish].

Büche, B., Möller, G. (2005). Rote Liste und Gesamtartenliste der holzbewohnenden Käfer (Coleoptera) von Berlin mit Angaben zu weiteren Arten. In Der Landesbeauftragte für Naturschutz und Landschaftspflege / Senatsverwaltung für Stadtentwicklung (Hrsg.): Rote Listen der gefährdeten Pflanzen und Tiere von Berlin. CD-ROM.

Chrzanowski, A., Mazur, A., Kuźmiński, R., Łabędzki, A. (2013). Biotopy czerwończyka nieparka (Lycaena dispar, Haworth, 1802) i czerwończyka fioletka (Lycaena helle Denis \& Schiffermüller, 1775) (Lycaenidae, Lepidoptera) oraz propozycja postępowania ochronnego na terenach administrowanych przez PGL Lasy Państwowe [Habitats of large copper (Lycaena dispar, Haworth, 1802) and violet copper (Lycaena helle, Denis \& Schiffermüller, 1775) (Lycaenidae, Lepidoptera) and protective actions on the territories administered by State Forests National Forest Holding]. Acta Sci. Pol. Silv. Colend. Ratio Ind. Lign., 12(3), 25-36 [in Polish].

Cmoluch, Z. (1989). Chrząszcze - Coleoptera, Kobielatkowate - Anthribidae [Beetles - Coleoptera, Anthribidae].
Klucze do oznaczania owadów Polski 19. Warszawa [in Polish].

Cunev, J., Majzlan, O. (1998). Ecosozological evaluation of beetles fauna Coleoptera of Nature reserve Vel'ký vrch v katastri Malé Kršteňany). Folia Faun. Slovaca, 3, 81-96.

Delbol, M. (2013). Catalogue des Curculionoidea de Belgique (Coleoptera: Polyphaga). Belgian J. Entom., 13, $1-95$.

Gutowski, J. M. (2006). Saproksyliczne chrząszcze [Saproxylic beetles]. Kosmos, 55(1), 53-73 [in Polish].

György, Z. (2006). Checklist of Hungarian Anthribidae and Urodontidae (Coleoptera). Fol. Entom. Hung., 67, 63-67.

Hammond, P. M. (1992). Species inventory. In B. Groombridge (Ed.), Global biodiversity. Status of the earth's living resources (pp. 17-39). London: Chapman and Hall.

Heijerman, T. (1993). Naamlijst van de snuitkevers van Nederland en het omliggende gebied (Curculionoidea: Curculionidae, Apionidae, Attelabidae, Urodontidae, Anthribidae en Nemonychidae). Nederl. Faun. Mededel., 5(3), 19-46.

Holloway, B. A. (1982). Anthribidae (Insecta: Coleoptera). Fauna New Zeal., 3, 1-272.

Holzinger, W. E., Frieß, T., Holzer, E., Mehlmauer, P. (2014). Xylobionte Käfer (Insecta: Coleoptera part.) in Wäldern des Biosphärenparks Wienerwald (Österreich: Niederösterreich, Wien). Wiss. Mitt. Niederösterr. Landesm., 25, 331-362.

Kuhnt, P. (1912). Illustrierte Bestimmungs - Tabellen der Käfer Deutschlands. Ein Handbuch zum genauen und leichten Bestimmen aller in Deutschland vorkommenden Käfer (pp. 2-16). Stuttgart: Lieferung.

Leder, H. (1872). Erster Nachtrag zu Edm. Reitter's Uebersicht der Käfer - Fauna von Mähren und Schlesien. Verh. Naturf. Ver. Brünn, 10, 86-139.

Löbl, I., Smetana, A. (Eds) (2011). Catalogue of Palearctic Coleoptera. Vol. 7. Curculionoidea I. Apollo Books.

Łukowski, A. (2015). Motyle dzienne (Lepidoptera: Hesperioidea, Papilionoidea) Trzemeszna i okolic [Butterflies (Lepidoptera: Hesperioidea, Papilionoidea) of Trzemeszno and its vicinity]. Wiad. Entom., 34(1), 29-42 [in Polish].

Mapa bioróżnorodności [Biodiversity map] (2015). Krajowa Sieć Informacji o Bioróżnorodności [The National Biodiversity Information Network]. Retrieved from http://baza.biomap.pl [in Polish].

Marczak, D., Masiarz, J. (2013). Rzadkie gatunki chrząszczy saproksylicznych (Insecta: Coleoptera) Kampinoskiego Parku Narodowego [Rare species of saproxylic beetles 
Bruder, D., Łukowski, A. (2016). New locality of rare saproxylic beetle Enedreytes sepicola (Fabricius, 1792) (Coleoptera: Anthribidae) in Poland with remarks on the biology and distribution of the species. Acta Sci. Pol. Silv. Colendar. Ratio Ind. Lignar., 15(3), 137-144. DOI: 10.17306/J.AFW.2016.3.16

(Insecta: Coleoptera)of Kampinos National Park]. Parki Nar. Rez. Przyr., 32(2), 73-84 [in Polish].

Marvaldi, A. E., Duckett, C. N., Kjer, K. M., Gillespie, J. J. (2009). Structural alignment of $18 \mathrm{~S}$ and $28 \mathrm{~S}$ rDNA sequences provides insights into phylogeny of Phytophaga (Coleoptera: Curculionoidea and Chrysomeloidea). Zool. Scripta, 38(1), 63-77.

Marvaldi, A. E., Sequeira, A. S., O’Brien, C. W., Farrell, B. D. (2002). Molecular and morphological phylogenetics of weevils (Coleoptera, Curculionoidea): do niche shifts accompany diversification? System. Biol., 51(5), 761-785.

Nakládal, O. (2011). Results of a faunistic survey of beetles (Coleoptera) in Vrapač National Nature Reserve (Czech Republic, Northern Moravia, Litovelské Pomoraví Protected Landscape Area) in 2009. Klapalekiana, 47, 213-236.

Nowicki, M. (1873). Verzeichniss galizischer Käfer. In Beiträge zur Insektenfauna Galiziens (pp. 7-52). Krakau.

Oberprieler, R. G., Marvaldi, A. E., Anserson, R. S. (2007). Weevils, weevils, weevils everywhere. Zootaxa, 1668, 491-520.

Plewa, R., Jaworski, T., Hilszczański, J. (2014). Martwe drewno a jakościowa i ilościowa struktura chrząszczy (Coleoptera) saproksylicznych w drzewostanach dębowych [Dead wood and community structure of saproxylic beetles (Coleoptera) in oak stands]. Stud. Mat. Centr. Eduk. Przyr.-Leśn., 16(41[4]), 279-299 [in Polish].

Polentz, G. (1949). Beiträge zur schlesischen Käferfauna. Entom. Blaetter Biol. Syst. Kaefer, 41-44, 25-30.

Rheinheimer, J. (2004). Illustrierter Katalog und Bibliographie der Anthribidae der Welt (Insecta: Coleoptera). Mitt. Entom. Vereins Stutt., 39, 3-242.

Schumann, E. (1908). Coleopteren der Provinz Posen, 15, $40-50$.

Schummel, Th. E. (1847). Bemerkungen über einige in Schlesien sehr seltene oder für die Fauna des Landes neue Arten der Rüsselkäfer-Gattungen Tropideres und Rhynchites. Übersicht der Arbeiten und Veränderungen der Schlesischen Gesellschaft für Vaterländische Kultur, Breslau: 1846: 94.

Stachowiak, P. (2002). Badania nad rozsiedleniem Anthribidae (Coleoptera) w Polsce [Studies on distribution of the Anthribidae (Coleoptera) in Poland]. Wiad. Entom., 20(3-4), 137-142 [in Polish].

Szulczewski, J. W. (1922). Chrząszcze Wielkopolski [Beetles of Wielkopolska]. Pr. Kom. Matem.-Przyr. PTPN, Ser. B, Nauki Biol., 3-4, 183-243 [in Polish].

Trella, T. (1930). Wykaz chrząszczów okolic Przemyśla. Uzupełnienia do dotychczasowych wykazów oraz rodziny: Lariidae, Anthribidae, Nemonychidae, Ipidae [List of beetles of Przemyśl and its vicinity. Additions to existing lists and family: Lariidae, Anthribidae, Nemonychidae, Ipidae]. Pol. Pism. Entom., 9(1-2), 33-39 [in Polish].

Tylkowski, S. (2014). Sosnowe bory bagienne jako refugium występowania chrząszczy (Coleoptera) saproksylicznych [Pine marsh forests as refuge of saproxylic beetles (Coleoptera)]. Stud. Mat. Centr. Eduk. Przyr.-Leśn., 16(41[4]), 279-299 [in Polish].

Wanat, M., Mokrzycki, T. (2005). A new checklist of the weevils of Poland (Coleoptera: Curculionoidea). Genus, 16(1), 69-117.

Wanat, M., Jałoszyński, P., Miłkowski, M., Ruta, R., Sawoniewicz, J. (2011). Nowe dane o występowaniu kobielatkowatych (Coleoptera: Anthribidae) w Polsce [New records of occurrence of fungus weevils (Coleoptera: Anthribidae) in Poland]. Wiad. Entom., 30(2), 69-83 [in Polish].

Weigel, J. A. V. (1806). Geographische, naturhistorische und technologische Beschreibung des souverainen Herzogthums Schlesien. Zehnter Theil. Verzeichniss der bisher entdeckten, in Schlesien lebenden Thiere. Berlin. 1-358.

Węgrzecki, M. (1932). Studja koleopterologiczne na wybrzeżu Polskiem. I. Dotychczasowe wyniki badań nad chrząszczami Helu [Study of beetles on Polish coast. I. The previous results of research on beetles of Hel]. Fragm. Faunist., 1, 465-505 [in Polish].

Widerberg, M. K., Ranius, T., Drobyshev, I., Nilsson, U., Lindbladh, M. (2012). Increased openness around retained oaks increases species richness of saproxylic beetles. Biodiv. Conserv., 21(12), 3035-3059. 


\section{NOWE STANOWISKO RZADKIEGO SAPROKSYLICZNEGO CHRZASZCZA ENEDREYTES SEPICOLA (FABRICIUS, 1792) (COLEOPTERA: ANTHRIBIDAE) W POLSCE WRAZ Z UWAGAMI O BIOLOGII I ROZMIESZCZENIU GATUNKU}

\section{ABSTRAKT}

Dotychczas w Polsce Enedreytes sepicola (Coleoptera: Anthribidae) został wykazany na miejscach rozproszonych niemal w całym kraju i wszędzie występował nielicznie. W pracy zebrano dane o występowaniu tego rzadko i lokalnie występującego przedstawiciela rodziny kobielatkowatych oraz opisano nowe stanowisko z Nadleśnictwa Nowa Sól w RDLP Zielona Góra. Osiem chrząszczy (5 3 i 3 ? $)$ zostało wyhodowanych w martwych gałęziach grabu pospolitego (Carpinus betulus). Stanowisko na terenie nadleśnictwa jest jednym z najdalej wysuniętych na zachód miejsc występowania gatunku na terenie Polski, a zarazem jest pierwszym jego stwierdzeniem w lasach województwa lubuskiego. Ponadto na podstawie literatury krajowej i zagranicznej przeprowadzono syntetyczny przegląd danych dotyczący biologii, ekologii i rozmieszczenia tego saproksylicznego gatunku.

Stowa kluczowe: Anthribidae, Coleoptera, Enedreytes sepicola, nowe stanowisko rozmieszczenie geograficzne 